\title{
BIOMASS BURNING AEROSOLS CHARACTERIZATION FROM GROUND BASED AND PROFILING MEASUREMENTS \\ Cristina Marin ${ }^{1,2, *}$, Jeni Vasilescu ${ }^{1}$, Luminita Marmureanu ${ }^{1}$, Dragos Ene ${ }^{1}$, Liliana Preda ${ }^{2}$, Mona Mihailescu $^{2}$
}

\author{
${ }^{I}$ National Institute of Research and Development for Optoelectronics, *cristina.marin@inoe.ro \\ ${ }^{2}$ University Politehnica of Bucharest, Faculty of Applied Sciences, Bucharest, Romania
}

\begin{abstract}
The study goal is to assess the chemical and optical properties of aerosols present in the lofted layers and at the ground. The biomass burning aerosols were evaluated in low level layers from multi-wavelength lidar measurements, while chemical composition at ground was assessed using an Aerosol Chemical Speciation Monitor (ACSM) and an Aethalometer. Classification of aerosol type and specific organic markers were used to explore the potential to sense the particles from the same origin at ground base and on profiles.
\end{abstract}

\section{INTRODUCTION}

Biomass burning aerosol (BBA) represents animportant part of the total aerosol emission, having both natural and anthropogenic sources. Zhang et al. [1] estimated that BBA represents $13 \%$ of the $\mathrm{PM}_{2.5}$, having seasonal variability, with greater fraction in the winter. Biomass burning emissions include BBA, which is primary composed of black carbon (BC) and organic carbon (OC); and important trace gases such as $\mathrm{CO}_{2}, \mathrm{CO}, \mathrm{SO}_{2}[2]$. The BBA effects include changes in the Earth radiative budgets [2] and human health [3].

Giving the spatial and temporal variability of aerosol distribution and composition, it is necessary to use assemble of different types of observation from passive and active techniques measurements, in order to achieve a good characterization of the aerosol.A major step forward and a challenge are represented nowadays by automatic aerosol classification using optical parameters. Lidar (Light detection and ranging) measurements provide microphysical and optical properties which permit aerosol classification or clustering [4].

Good options for automatic pattern recognition are neural networks, due to their unique mathematical approach. These have been already tested and extensively used in many domains related to classification such as protein structure, organic disorders, medicine and pharmacy [5]. The aerosol classification using only aerosol intensive optical parameters derived from multiwavelength lidar data as input, permit a fast identification of layers and their pattern[6]. New algorithms combine lidar profiles with column integrated measurements in order to retrieve aerosol concentration profiles such as: Liric[7].

For ground based measurements, spectral analysis [8] and mass spectrometry [9] are important tools to investigate aerosol composition, special ion markers being used for BBOA (biomass burning organic aerosol) assessment.

In this paper we evaluate the possibility of sensing the particles from the same origin in lofted layers measured by the lidar, and at ground base, by analyzing the chemical composition.

\section{METHODOLOGY}

Remote sensing and in-situ instruments present at the Bucharest, Romania site $\left(26.029^{\circ} \mathrm{E}, 44.048^{\circ} \mathrm{N}\right.$, $93 \mathrm{~m}$ above sea level) and corresponding measurements are used in order to characterize from both optical and chemical point of view the aerosol, from May to September 2016. The multiwavelenght lidar system, RALI, part of EARLINET is based on a 3 wavelength Nd:YAG laser and detection on 12 channels using both analogue and photoncounting [6].

In this paper, an algorithm for automatic aerosol classification from multiwavelength lidar data, based on Artificial Neural Networks, have been applied. The lidar data are used to calculate the intensive properties such as Ångstrom exponent (AE), color ratios, color indexes and lidar ratios, which are further presented to highly trained neural networks which pick up the most probable type of aerosols from several already defined 
classes[6]. A good classification process is strongly dependent on the physical content of the optical inputs and on their uncertainty.

The processing algorithm based on remote sensing measurements, used in this paper is LIRIC (Lidar/Radiometer Inversion Code)[7]. It combines pre-processed lidar, and column AERONET sunphotometer inversion data[7] in order to retrieve aerosols volume concentration profile for fine and coarse mode. The algorithm uses elastic lidar channels at $1064 \mathrm{~nm}, 532 \mathrm{~nm}$, $355 \mathrm{~nm}$ and when available the depolarization measurements (channel 532 cross). In this case, the aerosol in the coarse mode is divided into spherical coarse and spheroid coarse, besides the fine mode. The separation between the fine and coarse mode is made by finding the minimum radii from the AERONET size distribution in the $0.194-0.576 \mu \mathrm{m}$ range. Also the separation for the coarse mode is done using the sphericity parameter.

At ground base, chemical characterization for aerosol is achieved with an ACSM[10]. Using mass spectrometry principles, aerosol species are divided into organics (Org), ammonium $\left(\mathrm{NH}_{4}\right)$, nitrate $\left(\mathrm{NO}_{3}\right)$, chloride $(\mathrm{Chl})$ and sulfate $\left(\mathrm{SO}_{4}\right)$. The presences of BBA from mass spectrometry is evaluated using the f60 specific marker(ratio between $\mathrm{m} / \mathrm{z} 60$ concentration and organics concentration), due to signal at $\mathrm{m} / \mathrm{z} 60$ is attributed to levoglucosan and other "levoglucosan-like" species resulted from the pyrolysis of cellulose[9]. For a qualitatively evaluation of the aerosol degree of oxidation, two other markers are used: f43 and f44 (computed similarly as f60). An increase in $\mathrm{f} 44$ and a decrease in $\mathrm{f} 43$ indicates changes in aerosol volatility, thereby indicates the presence of oxidized aerosol [9].

Light absorption at seven wavelengths by aerosol particles is the principle of the Aethalometer[8]. Source apportionment of $\mathrm{BC}$ can be retrieved based on wavelength dependency of the absorption coefficient for different types of aerosols [8]. For the current paper, source apportionment for biomass burning and fossil fuel has been evaluated.

To assess the possible origin of upper layers we used forward dispersion model FLEXPART[11], based on fire emission rate estimated from Modis orbital satellites. FLEXPART uses meteorological data as input for the Lagrangian particle dispersion model and it can provide backward and forward simulations of particle trajectories.

\section{RESULTS}

Five months, from May to September 2016, of lidar, mass spectrometry and absorption measurements have been analyzed. At ground the measurements are characterized by higher average concentration for organics $\left(5.4 \mu \mathrm{g} / \mathrm{m}^{3}\right)$ than the other chemical species $\left(1.7 \mu \mathrm{g} / \mathrm{m}^{3}\right.$ for $\mathrm{NH}_{4}, 0.77$ $\mu \mathrm{g} / \mathrm{m}^{3}$ for $\mathrm{NO}_{3}$ and $2.12 \mu \mathrm{g} / \mathrm{m}^{3}$ for $\left.\mathrm{SO}_{4}\right)$, while spectral analysis retrieves average concentrations of $0.08 \mu \mathrm{g} / \mathrm{m}^{3}$ for BBA and $1.15 \mu \mathrm{g} / \mathrm{m}^{3}$ for fossil fuel BC. Two major peaks for BBA concentration are noticeable on $12^{\text {th }}$ of July $\left(2.52 \mu \mathrm{g} / \mathrm{m}^{3}\right)$ and $30^{\text {th }}$ of September $\left(2.01 \mu \mathrm{g} / \mathrm{m}^{3}\right)$.

The lidar retrievals and automatic classification algorithm highlight that fine and low depolarizing particles are predominant components of the lower layers during the measurements period, representing approximately $70 \%$ of the analyzed cases. During the five months of measurements, only few cases of proper meteorological conditions which permit aerosol mixing and lofted layers descending to the ground have been encountered. One of these study cases is identified on $29^{\text {th }}$ September 2016, and is further analyzed.

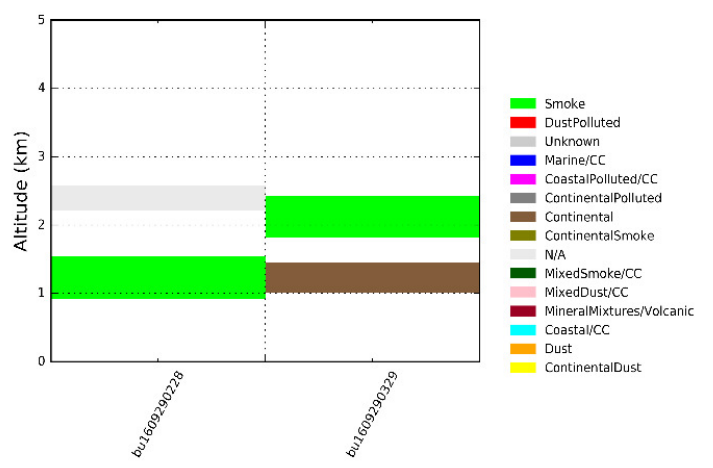

Figure 1.Types of aerosols retrieved using automated classification algorithm on $29^{\text {th }}$ September 2016

During $28^{\text {th }}$ to $30^{\text {th }}$ September 2016 the BBA aerosols have been present in lofted layers and at the ground. The automatic classification algorithm pin points the presence of smoke, continental and continental polluted as predominant components characteristic for the lower layers (Figure 1). 
For the LIRIC algorithm computed for $29^{\text {th }}$ September 2016 only elastic channels without depolarization measurements have been used. The vertical distribution of coarse and fine aerosol and vertical profiles of backscatter coefficient are illustrated in Figure 2. Fine particles are dominant on the entire vertical profile, but a layer of fine aerosol is emphasized from 1 to $2 \mathrm{~km}$. This result is in accordance with the layer of BBA retrieved by the automatic classification algorithm.

At ground level, the average mass concentrations measured for organics, sulfate, nitrate and ammonium were $7.54 \mu \mathrm{g} / \mathrm{m}^{3}, 1.82 \mu \mathrm{g} / \mathrm{m}^{3}, 1.6$ $\mu \mathrm{g} / \mathrm{m}^{3}$, and $2.6 \mu \mathrm{g} / \mathrm{m}^{3}$ respectively.Around $70 \%$ of the total aerosol sampled exceeded the background level of f60 marker for BBA, while theaging markers 444 and 443 indicates mainly the presence of particles with low volatility, and also semi-volatility attributed to oxidized aerosol. A special interest is given to last aerosol sampled on $29^{\text {th }}$ September, 22.10 UTC, characterized by high organics concentration, and semi-volatile BBA aerosol. The sampled aerosols are classified as oxygenated BBA, which are characteristic for BBA or smoke aerosols emitted in the atmosphere by vegetation fires and could by associated with long-range transport.

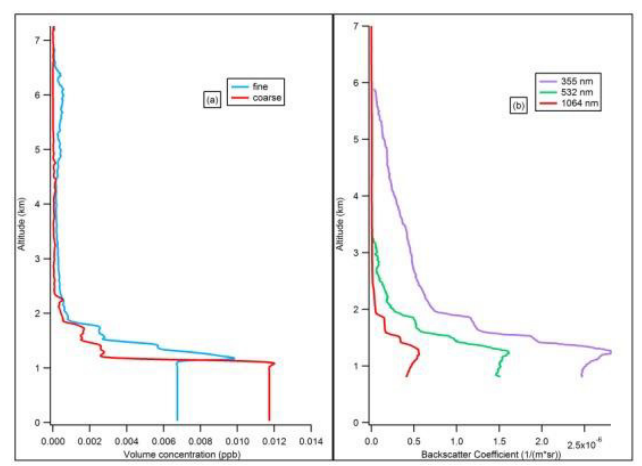

Figure 2. a) LIRIC retrieval for $29^{\text {th }}$ September. Altitude vs. volume concentration for fine (blue) and coarse (red) aerosol; b) Vertical profiles of backscatter coefficient at $355 \mathrm{~nm}$ (purple), $532 \mathrm{~nm}$ (green) and $1064 \mathrm{~nm}$ (red) derived from lidar measurements for $29^{\text {th }}$ September 2016

The organic fraction at $\mathrm{m} / \mathrm{z} 60$ and black carbon (BC) emitted from biomass burning retrieved from Aethalometer (based on differential abortion at 370 and $880 \mathrm{~nm}$ ) have the same appearances highlighting the presence of BBA (Figure 3). The time series, presented in UTC time, illustrates a diurnal trend, with higher values in the afternoon (17-18 UTC), and minimum values at noon.

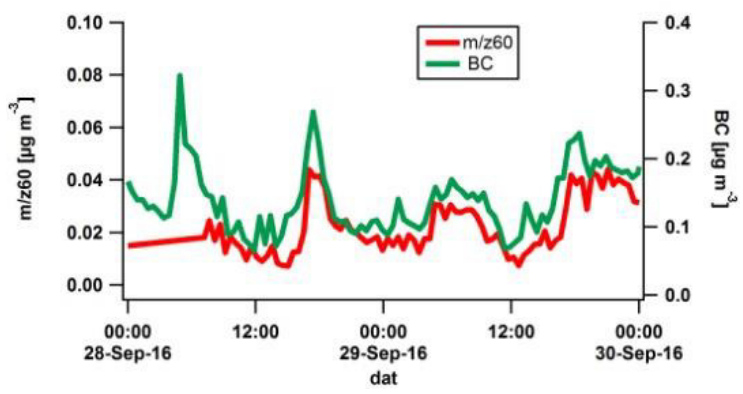

Figure 3. Time series for $\mathrm{m} / \mathrm{z} 60$ (red) and BC (green) mass concentration

The atmospheric layers from long range transport in the sample site were evaluated using the FLEXPART model. Specific sets of particles for $\mathrm{BBA}$, based on a mixture between organics and $\mathrm{BC}$ was used to compute the dispersion from sources. The model was set-up assimilating Aqua and Terra fire spot satellite data, and using fire radiative power (FRP) retrieval as input in the model that was transformed in emission rate, using emission coefficient established by Ichoku et al., 2014[12]. The period assimilated was between $27^{\text {th }}$ and $29^{\text {th }}$ September when hot spots with high degree of confidence and significant value of FRP was taking into account.

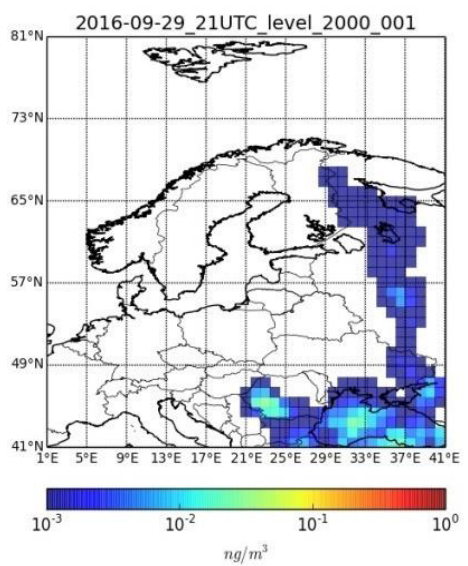

Figure 4. BBA dispersion retrieved from FLEXPART, on $29^{\text {th }}$ September 2016, at $2000 m$ altitude

Important satellite thermal anomalies have been detected in the south part of Europe that influence the upper layers at $2000 \mathrm{~m}$ as shown in Figure 4. The output model also underlines influences from long range transport at ground base $100 \mathrm{~m}$ (not shown). 


\section{CONCLUSIONS}

Independent assessments of biomass burning aerosols presence at the Bucharest site during May-September 2016 have been assessed using in situ and remote sensing measurements. Chemical composition, specific markers and differentiated spectral absorption pin pointed the BBA characterizes, including oxidation state and potential source highlighting the possible longrange transport. In the same time the low level layers of aerosols have been evaluated from multiwavelength lidar measurements. The LIRIC algorithm identified the fine particle volume concentrations, while automatic classification algorithm pin pointed the predominant component.The $29^{\text {th }}$ September 2016 case is intensely analyzed proving the potential to sense the same BBA particles at ground base and on profiles.

\section{ACKNOWLEDGEMENTS}

The research leading to these results has received funding from the European Union's Horizon 2020 Research and Innovation Programme, under Grant Agreement no 692014-ECARS and from the National Core Program- PN 16400101.

\section{References}

[1] Zhang, X., Hecobian,A., Zheng, M., Frank, N. H., Weber, R. J., 2010: Biomassburning impact on PM2.5 over thesoutheastern US during 2007: integrating chemically speciated FRM filter measurements, MODIS fire counts and PMF analysis, Atmos. Chem. Phys. 10, 6839-6853.

[2] Jacobson, M. Z., 2014: Effects of biomassburning on climate, accounting for heat and moisture fluxes, black and brown carbon, and cloud absorption effects, J. Geophys. Res. Atmos., 119, 8980-9002.

[3] Sigsgaard, T., et al., 2015: Health impacts of anthropogenic biomass burning in the developed world, EurRespir J.,46(6):1577-1588.doi: 10.1183/13993003.01865-2014.

[4] Groß, S., Esselborn, M., Weinzierl, B., Wirth, M., Fix, A., Petzold, A., 2013: Aerosol classification by air borne high spectral resolution lidar observations, Atmos. Chem. Phys., 13, 2487-2505.
[5] Li, H., Liu, C., Burge, L., Southerland, W., 2012: Classification of Protein 3D StructuresUsing Artificial Neural Network, $I J M L C, 2(6)$.

[6] Nicolae, D., Vasilescu, J., Talianu, C., Dandocsi, A., 2016: Independent retrieval of aerosol type from lidar,EPJ Web of Conferences, http://dx.doi.org/10.1051/epjconf/201611918002.

[7] Chaikovsky, A.,et al., 2016: Lidar-Radiometer Inversion Code (LIRIC) for theretrieval of vertical aerosol properties from combined lidar/radiometer data: development and distribution in EARLINET, Atmos. Meas. Tech., 9, 1181-1205.

[8] Lewis,K., Arnott, W.P., Moosmüller, H., Wold, C.E., 2008: Strong spectral variation of biomass smoke light absorption and single scattering albedo observed with a novel dual-wavelength photoacoustic instrument, J. Geophys. Res, 113, D16.

[9] Adler, G.,Flores, J.M., AboRiziq, A., Borrmann, S., Rudich, Y., 2011: Chemical, physical, andopticalevolution of biomassburningaerosols: a case study, Atmos. Chem. Phys., 11, 14911503.

[10]Ng, N.L., Herndon, S. C., Trimborn, A., Canagaratna, M.R., Croteau, P.L., Onasch, T.B., Sueper, D, Worsnop, D.R., Zhang, Q., Sun, Y.L., Jayne, J.T., 2011: An Aerosol Chemical Speciation Monitor (ACSM) for Routine Monitoring of the Composition and Mass Concentrations of Ambient Aerosol, Aerosol Sci. Technol., 45, 780-794.

[11]Stohl, A., Forster, C., Frank, A.,Seibert, P.,Wotawa, G., 2005:Technical note: The Lagrangian particle dispersion model FLEXPART version 6.2, Atmos. Chem. Phys., 5, 2461-2474.

[12]Ichoku, C., and Ellison, L., 2014: Global topdownsmoke-aerosol emissions estimation using satellite fire radiative power measurements, Atmos. Chem. Phys., 14(13), 6643-6667. 